\title{
Meeting the potential for mentoring in Initial Teacher Education: mentors' perspectives from the Lifelong Learning Sector
}

\author{
Rebecca Eliahoo \\ University of Westminster \\ Westminster Partnership CETT
}

\begin{abstract}
The Lifelong Learning Sector's very diversity has produced a variety of mentoring practice, contested notions of subject pedagogy, and a continuum of mentoring from the 'jobsworth' to the master mentor. This article reports on two linked action research projects which investigate the context and challenges of mentoring in the Lifelong Learning Sector (LLS) following a raft of reforms to Initial Teacher Training (ITT) (DfES, 2002; DfES, 2004; Ofsted, 2003). In the research, mentors were asked to reflect on their experiences, interpretations of and training for their role and how they support subject pedagogy. The conclusion suggests that the government's and regulatory bodies' conflation of subject knowledge with subject pedagogy adds to the lack of coherent policy towards mentoring teacher trainees in the LLS; that mentor training should be re-focused; and that mentoring should be as well funded and supported in the LLS as it is in the schools sector.
\end{abstract}

Key words

Mentoring; Mentor Training; Initial Teacher Training; Lifelong Learning Sector; Subject Pedagogy.

\section{Introduction and background \\ Mentoring has been linked to better career advancement, more career development opportunities, higher levels of career maturity and greater overall job satisfaction by protégés.'}

(McDowall-Long, 2004: p. 520)

The impetus for this research into mentoring was a desire to investigate the psycho-social and career support available for teacher trainees coming to grips with teaching and studying simultaneously. The ample literature on mentoring in industry and schools reflects McDowall-Long's (2004: p. 520) views on the efficacy of mentoring as a developmental relationship. The government has promoted mentoring (DfES, 2004: p. 4), not only as an effective method of advice and support for novice teachers, but as the cornerstone for the development of subject pedagogy in generic teacher training in the LLS. This article explores mentors' experiences in this sector and asks whether mentors are adequately trained, funded and supported in this role.

Mentors are now the work-based learning link outside the academic classroom (DfES, 2004: p. 8; Ofsted, 2003: p. 21) and their role is to induct mentees into a community of practice and to encourage them to forge a new identity as a teacher in the LLS. Or as Bob ${ }^{1}$, an experienced plasterer now training as a lecturer in a Further Education college put it:

"Building sites are not a friendly place to be at times...I had found myself talking to [college] students like they were one of the boys on the building site and that's a big no-no. You can't give [students] a clip round the ear if they get something wrong."

This article is based on the writer's action research projects which examined mentoring in the Westminster Partnership CETT $^{2}$ as an important and growing area of activity. Although the provision of mentor training is widespread, it remains problematic in some areas (Ofsted, 2009: p.5), for example, not all trainees are allocated mentors and of those allocated, not all match their mentee's subject specialism; some mentors are not qualified teachers and some have little or no training and, indeed, no wish to be a mentor. Yet mentoring has the potential to assuage the effects on trainees of the sector's challenging environment, as the psychosocial functions of mentoring improve mentees' sense of competence and professional effectiveness (Noe, 1988: p. 459).

\section{An opaque mentoring policy}

Ofsted's survey in $2003^{3}$ had found that there were few opportunities for trainees to learn how to teach their specialist subjects and a lack of systematic mentoring and support in the workplace. Ofsted was highlighting two separate issues: firstly, the lack of subject-specific training for teaching a specialist subject or vocational area; and secondly, the lack of effective mentoring, observation and feedback on teaching in the workplace which the inspectorate felt inhibited trainees' progress significantly.

\footnotetext{
${ }^{1}$ All names of mentors used are pseudonyms and the research is anonymised.

2 The Westminster Partnership Centre for Excellence in Teacher Training was founded by the University of Westminster and Oxford Brookes University to research and share good practice, to promote equality and diversity and to develop teacher training in the Lifelong Learning Sector.

${ }^{3}$ In 2001, Ofsted (2003) became responsible for the inspection of FE teacher training and around the same time, the Further Education National Training Organisation (FENTO) introduced new national regulations for teacher training.
} 
The government's programme of reforms (DfES, 2004: p. 7), however, led to a conflation of mentoring with subject-specific pedagogy. The DfES document states:
'...Mentoring of teachers in the workplace: an essential aim of the training is that teachers should have the skills of teaching in their own specialist or curriculum area. The taught elements of teacher training courses are likely to be generic, because of the range of teachers taking part. Subject-specific skills must be acquired in the teachers' workplace and from vocational or academic experience. Mentoring, either by line managers, subject experts or experienced teachers in related curriculum areas, is essential.'

(ibid, p. 8)

Suddenly, subject specific pedagogy was to be delivered through mentoring; this had not been Ofsted's stated intention in its 2003 survey according to inspectors who wrote the report.

It is also unclear whether the mentor's role in the training and induction of teacher trainees centres on subject knowledge or subject pedagogy. Government documents fluctuate between mentoring as a support for the trainee's knowledge about teaching their subject and mentoring as a support for the trainee's knowledge and skills in their subject. These are very different conceptions and yet the policy seems to move between the two as if they were the same. This is particularly problematic because the government is borrowing from the schools sector, where one of the main roles of mentoring is to update or top up actual subject knowledge. The 2008 Ofsted Chief Inspector's Annual Report states:

The quality of support by mentors has improved especially in Further Education teacher training where arrangements for mentoring in the workplace are now integral to all training programmes. Nevertheless, not all mentors give trainees enough subject-specific feedback so that they are clear about where they need to improve their subject knowledge.'

(2008b p. 50)

If the government wants mentoring in the LLS to develop trainees' subject knowledge, this begs the question of what they mean by subject knowledge, particularly in vocational areas. Is there an agreed syllabus of what constitutes different levels of subject knowledge for teachers in the LLS? Is there sufficient capacity within the sector to deliver such curricula? If the government wants mentoring in the LLS to support subject pedagogy, is there strong evidence to support the idea that each subject has a distinctive pedagogy? (Fisher and Webb 2006: p. 341)

\section{A tale of two sectors}

In June 2007, the Department for Education and Skills (DfES) was split into two: the Department for Innovation, Universities and Skills (DIUS) which became responsible for adult learning, some parts of further education, higher education, skills, science and innovation and the Department for Children, Schools and Families (DCSF). Two years later, DIUS was merged into the newly formed Department for Business Innovation and Skills (DBIS). These two government departments' and Ofsted's approaches to teacher training reform were based on their experience with secondary school models (Lucas, 2007: p.95). To suggest that the school experience is akin to that in the LLS ignores the significant differences between the schools and lifelong learning sectors, which make the provision of effective mentoring in the latter sector problematic. In schools, teacher training qualifications are subject-specific and trainees are taught how to teach the subject matter as part of their course; school Initial Teacher Education is overwhelmingly pre-service, all-graduate and highly evolved in terms of links between training and placement providers (Thompson and Robinson, 2008: p. 164). There is also a legal requirement for schools to provide subjectspecific mentoring, without which the graduating trainee would not be given Qualified Teacher Status. There is no such provision in the LLS.

In the schools sector, the curriculum comprises roughly 16 subjects but in the LLS, there are over 200 subjects (Crawley, 2005) from hairdressing to history and plumbing to philosophy. This raises difficulties due to the context and infrastructure of the LLS (Cunningham, 2005: p. 20). Primary and secondary school teachers follow the National Curriculum which standardised the delivery of education to all pupils of compulsory school age; identified the range of subjects; the ages at which these should be taught; and set attainment levels and targets. In the LSS, there is no overarching national curriculum. LLS lecturers may be teaching on qualifications such as GCSEs and A levels as well as National Vocational Qualifications, Business and Technology Education Council (BTEC) awards, the 14-19 Diploma, Access to Higher Education courses, foundation degrees, courses at different levels accredited by professional bodies (such as the Council for Awards in Children's Care and Education (CACHE) Level 2 Early Years Care and Education for nursery teachers; or the National Council for the Training of Journalists' Level 4 postgraduate course). Finding an appropriate mentor is therefore complicated by the variety and degree of specialisation of qualifications. For example, on some specialist courses, there may only be one subject expert and that may be the trainee teacher. Is it appropriate for a journalism lecturer to be mentored by a lecturer in English literature who has never set foot in a newsroom?

In the LLS, small numbers of staff may be employed in a particular subject area (especially by training companies where the trainee may be the only person teaching a subject) and there may be no appropriately qualified member of staff to take on the role of mentor (Ofsted, 2008a: p. 11). Mentoring does not work well in the context of small providers or work-based learning where mentors are hard to find. Yet an increasing proportion of teacher trainees 
who opt to work in the LLS are drawn from adult or community settings, for example, in a hospital or prison or with private providers of work-based learning, as a recent Ofsted report confirmed (2008a).

Yet, despite its challenges, the LLS achieves significant success (Thomson, 2009). More than 2.8 million adults improved their basic skills between 2001/02 and 2007/08 (against the target of 2.25 million by 2010) and eight out of ten learners in 2008 achieved the qualification they started out on - a target the sector was not expected to achieve until 2010. Moreover, the LLS has a good success rate with 'problem' pupils, whose former schools have refused to put them in for exams fearing that their low achievement would damage league table results. These are the same schools, incidentally, where teachers are better paid and pupils are better funded than their LLS counterparts; and it is the school sector which is the source for the mentoring model being implemented in the LLS.

\section{A short literature review}

A number of educational theories and concepts throw light on the reasons why institutions promote mentoring as good practice, and why the government has chosen to use mentoring as a tool for the support of subject pedagogy. A theory of mentoring, however, is proving elusive according to Bozeman and Feeney (2007) who posit that the most important rule for developing a useful concept is to be able to state its boundary conditions. Their 'thought experiment' illustrates the inability of mentoring theory to be distinguished from related activities (such as training or socialisation). In the 'thought experiment', an older experienced mentor's relationship with his protégé throws up a number of questions: Is acknowledgement required for a mentoring relationship? Who is the mentor if they help each other? When does mentoring begin and end? The authors believe that the depth and sweep of concepts such as mentoring are part of the reasons why a 'theory of mentoring' is problematic. Their conclusion is that there are many reasons why mentoring theory is underdeveloped: it is multidisciplinary and therefore draws from many theoretical perspectives; and mentoring research tends to be instrumental in its motivation.

Kram's seminal research on mentoring (1985) defined it in terms of older individuals serving as role models and providing career guidance, task assistance and social support to younger colleagues. This definition draws on humanistic approaches as exemplified by Rogers (Tusting and Barton, 2003: p. 23) where the role of mentor is concerned principally with empowering student teachers and with promoting autonomy and professional growth (Hankey, 2004: p. 390).

Kram's research, however, was in industry with different models of power relationships. Colley's (2002: p.259) deconstruction of the mythical representations of mentoring and her application of a feminist, dialectical-materialist perspective to mentoring sounds a note of caution about mentoring in the field of teacher education. She identifies four distinct historical stages in the development of mentoring, revealing that it has shifted from dominant groupings reproducing their own power, to subordinate groupings reproducing their own oppression. She takes as an example the increasing use of non-professional, poorly paid and ill-trained staff to mentor socially excluded youth.

\section{'Even for those professional staff engaged in mentoring, the resource-intensive nature of the work, and the emotional demands it places upon mentors, risk creating high levels of stress.'}

(Hulbert; in Colley, 2002: p. 268)

This raises interesting questions about mentors' roles in the context of ITT in the LLS; the level and substance of professional training they receive; and whether this training prepares them for the emotional demands of mentoring. Ofsted inspections (2006) describe mentor training as inconsistent, which contributes to the lack of clarity in mentors' perceptions of their own role, its professional boundaries and which mentoring style they should use (Ingleby and Hunt, 2008: p. 68).

\section{Summary of research design}

The writer undertook an action research project which was primarily qualitative in nature (only a relatively small number of questionnaires were returned by mentors and mentees) and a case study enquiring into the nature of mentors' experiences supporting ITT trainees in the LLS. Both pieces of research aimed to gain a better understanding of mentors' roles and achievements in developing their mentees' subject pedagogy; as well as to collect data to inform and improve mentoring schemes in the Centre for Excellence in Teacher Training (CETT) in order to make these more effective and fairer in future. The Department for Innovations, Universities and Skills (DIUS) seemed to propound mentoring as the principal plank for imparting subject pedagogy to trainees and these inquiries asked mentors to what extent this is possible within the constraints of their own practice.

The case study was qualitative and focused on issues of equal opportunity in the provision of mentoring, especially for those teacher trainees who work in Adult and Community Learning (ACL), prison education and Work Based Learning (WBL) (Eliahoo, 2008: p. 2; Samson, 2008: p. 4). An increasing proportion of teacher trainees who opt to work in the LLS are drawn from adult or community settings, for example, in a hospital or prison or with private providers of WBL (Ofsted, 2008: p. 4). The case study aimed to examine the impact of the new mentoring requirements on the quality of ITT in adult and community education. 
Even within Further Education colleges, however, there are instances where part-time or agency staff have not been provided with mentors, as some employers fear that providing them with a mentor may constitute a legal contract and may change their status from temporary to permanent staff.

- Five mentors were interviewed twice over the course of an academic year and two mentors once, using semistructured face-to-face interviews in January 2008 and using telephone interviews in June 2008. Four mentors had been teaching for over five years, one had taught for over ten years, one for over 25 years and one for over 30 years. The mentors were chosen or referred to the writer because of their proven track record as mentors and their commitment to the trainees and their institutions. It took some time to find mentors who were sufficiently experienced, skilled and willing to take part in the interviews. Some mentors who were approached had either changed roles, left their institution or had not had recent mentoring experience.

- Telephone interviews were used to compare and contrast the mentoring schemes used by a secondary and a tertiary Post-Graduate Certificate in Education (PGCE) course leader in the same Higher Education Institution in the South of England.

- 200 questionnaires were sent out to consortium trainees and 80 responses were received (a 40 percent response rate). Mentee questionnaires were emailed to the course leaders in the six colleges who disseminated them to their teacher trainees.

- Mentor questionnaires were emailed directly to 81 mentors who supported the trainees across the consortium colleges and 21 replies were received (a 26 percent response rate).

- 81 mentors were invited to a mentor forum in June and seven mentors attended.

- The case study included interviews with Programme Managers from two Adult and Community Education colleges, one with a primarily vocational market and the other with a primarily academic market; and a teacher trainee in WBL. Among the questions asked were: What were subject specific mentors asked to do? How were they chosen and trained? What impact have they had on trainees? How have you monitored your mentoring arrangements? What problems arose?

- Mentors took part and evaluated a mentor training module at Level 7.

A number of themes emerged from the research: firstly, mentors' differing understanding of their roles within ITT in the LLS; secondly, the conflation of subject knowledge and subject pedagogy; thirdly, the wider effects of mentoring; and finally, the need for adequate mentor training combined with solid institutional frameworks for mentoring.

\section{How mentors interpret their role}

The research data show that mentoring is not solely a technical issue that can be enabled by a simple training programme of the kind that the majority of mentors receive. Indeed, half the mentors who replied to questionnaires requested more specific training on how to perform teaching observations and give feedback; and during interviews and a mentor forum, practitioners wanted to discuss how to deal with what Feldman (1999: p. 262) calls 'toxic' mentees and/or colleagues where an escalation of destructive behaviour leads to dysfunctional work relationships.

In order to support their mentees and survive as mentors, it is vital for mentors to develop a profound understanding of human nature, including its darker elements. Two mentors explained that they had needed to develop keen political instincts and use the 'dark arts' of mentoring to prevent what they judged to be institutional bullying against their mentees. The strategies they used to protect the mentees (whom they were told in confidence had been earmarked for redundancy) not only helped the latter, but also prevented their institutions from becoming the subject of employment tribunal cases.

In their interviews, mentors highlighted a number of aspects of their role: all the mentors interviewed had adopted a range of affective objectives (Curzon, 2004: p. 165) for their trainees which went well beyond the professional and official agendas of mentoring. Mentors needed to develop good listening skills while mentees talk through their fears and issues, the successes of their teaching week, how to manage workloads and how to avoid stress or frustration. This adoption of affective objectives is significant as it reflects the new demands on colleges and lecturers (Lucas 2007: p. 96) which place greater emphasis on motivating learners, dealing with vulnerable learners and helping with broader knowledge and key skills. These aspects of teaching lie in what Schon (1983: p. 48) would call 'the swampy lowlands' of professional knowledge where mentors are asked to handle myriad mentee problems from managing a class to coping with managers' deadlines.

Edward, et al (2007) point out a number of difficulties besetting the LLS: high staff turnover; over-reliance on parttime and agency staff; under-funding compared with the schools sector; the speed and extent of institutional, curricular and policy changes; and the lack of staff consultation and involvement in all of the above. These have all worn staff down and exacerbated staff recruitment and retention problems. The pressures on lecturers are unremitting and none more so than on new staff who are also expected to provide cover across subject areas, in some cases, up to 100 hours teaching a year. This leads to difficulties for novice teachers who become anxious about managing a class they have never met and teaching a topic they have not prepared for. 
Secondly, mentors stressed the value of taking enough time to establish a good working relationship with their mentee, which is why remission for both mentors and mentees is crucial. A good rapport can lay the foundation for honest and open reflection as a precursor to self improvement. This is significant as remission or payment for mentors remains problematic; for example, in one university CertEd/PGCE consortium alone, mentors can receive anything from 20 hours payment or remission a year, to payment of up to $£ 685$ per year. Remission from teaching for teacher trainees also remains unequal across this consortium. Those in FE colleges in the consortium do get some remission: from one to three hours' remission a week - those who do not get any remission have to cram their teaching hours into the rest of the week, leaving little time to establish a good working relationship with their mentor and increasing the pressures of coping with their job and their training.

The third aspect of mentors' roles relates to mentors' goals and what differences they hope to make to their mentee. Agency and part-time mentees' concerns were manifold: lower pay and fewer staff benefits, 'hot-desking' and lack of managerial support. These mentees fear that if they complain, they will be quietly dropped from the teaching team. This can lead them to feel that their professional identity remains peripheral and contested within the department. Susan is a retired Head of Department and teacher educator who felt that her role as an outsider enabled her firstly, to tackle some of her agency mentees' difficulties (such as inadequate rooming and lack of payment for work such as writing University and Colleges Admissions Service (UCAS) references) and secondly, to give her mentees the confidence to speak up for themselves.

Some mentors saw their role as counter-balancing what they perceive as troublesome contemporary theories of generic good practice, which they label disparagingly as the 'touch-feely' approach that lesson observers want to see. For example, Malcolm does not identify with current models of student-centred teaching. He has taught mathematics in the UK and abroad both at university and in a college for 25 years and argues for traditional mathematics teaching methods that build up confidence and reinforce learning. Although he sees the benefits of using, for example, the discovery method in lower level mathematics teaching, he argues that this does not work at higher levels, especially in FE, where teachers are funded for fewer hours than their school counterparts.

"Maths is the most completely abstract subject and students tend to get maths anxiety when they don't understand a problem. Then they switch off. Flashy IT packages, the Standards Unit stuff, discovery, group work - it looks nice and it is fun but none of that stops the panic. In a college, we have to do catch-up with students who got Grades E, F or $G$ and they need to get to Grade C in a year."

His model of mentoring uses the craft knowledge of teaching mathematics at those levels to induct mathematics teacher trainees into the realities of the sector. This is reflected in Frank Coffield's report identifying ten general principles to underpin the core processes of teaching and learning within the LLS (2008: p. 11). He sees these principles providing only a framework which must be adapted to the different subject areas taught in the sector because:

'...the pedagogy needed to teach engineering is obviously different from that needed to teach childcare. If not, we shall end up with rather mechanically-minded nurses and child-centred engineers.'

(Coffield, 2008: p. 13)

Mentoring is complicated by the disintegration of disciplines within the LLS. During my research, I came across the following: numeracy as a subject might appear in the Skills for Life department of a college as well as the mathematics department; a physics teacher might teach chemistry, biology, mathematics or even anatomy on a beauty course; a photography lecturer might be asked to teach history of art or graphic design; a construction teacher might also be asked to teach plumbing or electrical installation. In other words, lecturers are seen as interchangeable units and increasingly feel that there is a lack of regard for their expertise in their own discipline. Which subject specialists should be appointed to mentor such polymaths? This curricular super-complexity makes mentoring based on subject specialism hard to implement and has major implications for the establishment of valid and valued subject specialist mentoring.

Much of the literature on mentoring identifies potential negative consequences of mentoring for protégés; for example, these relationships can build a sense of dependency that hampers mentees' abilities to function independently (Feldman, 1999: p. 250). However, there are also potential negative consequences for mentors, such as heightened feelings of betrayal and anger (Kram, 1985: p. 40). These feelings usually stem from perceptions that protégés do not reciprocate adequately or appropriately enough for the time and energy mentors invest in them (Feldman, 1999: p. 250). Two mentors highlighted what for them was the downside of mentoring. Roberta spoke of her frustration with a part-time mentee who was severely dyslexic yet was unwilling to receive support for this. Although the majority of mentors said they enjoyed mentoring and found that observing and mentoring mentees was beneficial to their own practice, this was not always the case.

\section{Conclusion}

The comparison between the schools and Lifelong Learning Sectors raises concerns about the funding and framework in place in the LLS. Geoffrey (PGCE course leader responsible for the schools sector partnership in an HEI in the South of England) says that school mentors' input is crucial as they know what CPD, staff development 
or in-service training activities are available for the orchestration of subject support. They do not attempt to do everything themselves. The schools mentors are trained by the HEI and given one hour a week (36 hours a year per mentee) to de-brief what happened in the placement and to plan the week ahead as well as orchestrating the subject support, rather than being sole repository of subject knowledge and subject pedagogy. The contrast with the postcompulsory PGCE is stark, according to Geoffrey's colleague, Joy, who is course leader for the post-compulsory PGCE:

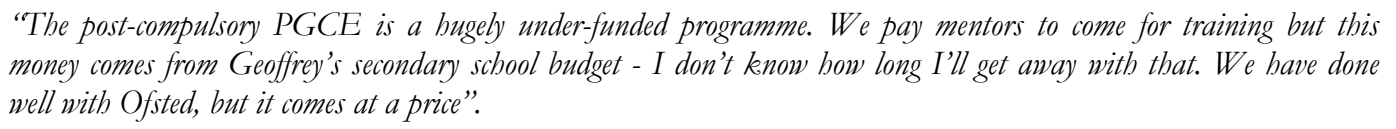

Ever since incorporation in 1992 - and unlike the schools sector - colleges have been encouraged to see themselves as 'businesses'. Some heads of department are therefore understandably reluctant to release their best teachers for mentoring, as this requires cover for the mentors' classes and a possible lowering of results. College managers have become results-driven and do not yet place a value on the benefits of meaningful mentoring and the time it requires. Employers in the WBL sector are already under-staffed with trainers teaching 24 hours over a week, often over several sites. Some employers in the North London area said at a Centre for Excellence in Teacher Training (CETT) meeting in August 2008 that either no-one in their company was available for mentoring or that the person who needed to be mentored was their highest qualified and most experienced member of staff.

The situation is not all gloom and doom. Evidence shows (Standards Unit 2007: p. 25) that there is a wealth of ideas, innovation and motivation focused on establishing effective mentoring schemes within ITT. The mentors interviewed were engaged, creative and enthusiastic about supporting teacher trainees; they identified the reciprocal benefits of mentoring and took an active part in mentoring and training schemes which are being developed and evaluated across the CETT.

The government policy of making mentoring the cornerstone of subject specialist support in ITT raises a number of challenges for the sector, not the least of which is the role of a supportive institutional framework which Cunningham (2007) describes as an 'architecture' for mentoring (for example, ways of incentivising staff to become mentors. Further research could focus on extracting and evaluating the active ingredients of successful mentoring relationships for use in the sector.

\section{References}

Bozeman, B., Feeney, M.K. (2007) 'Toward a Useful Theory of Mentoring: A Conceptual Analysis and Critique' Administration \& Society Vol. 39 , No. 6, pp. 719-739. http://dx.doi.org/10.1177/0095399707304119

Coffield, F. (2008) Just Suppose Teaching And Learning Became The First Priority. London: Learning and Skills Network.

Colley, H. (2002) 'A Rough Guide To The History Of Mentoring From A Marxist Feminist Perspective' Journal of Education for Teacbing Vol. 28, No. 3, pp. 257-273. http://dx.doi.org/10.1080/0260747022000021403

Crawley, J. (2005) In At The Deep End London: David Fulton.

Cunningham, B. (2005) Mentoring Teachers in Post Compulsory Education. London: David Fulton Publishers.

Cunningham, B. (2007) 'All The Right Features: Towards An "Architecture" For Mentoring Trainee Teachers In UK Further Education Colleges', Journal of Education for Teaching Vol. 33, No. 1, pp. 83 - 97. http://dx.doi.org/10.1080/02607470601098351

Curzon, L. B. (2004) Teaching in Further Education: An Outline of Principles and Practice London: Continuum.

DfES (2002) Success for All: Reforming Further Education and Training. London: Department for Education and Skills.

DfES (2004) Equipping our Teachers for the Future: Reforming Initial Teacher Training for the Learning and Skills Sector. London: Department for Education and Skills.

Edward, S., Coffield, F., Steer, R., Gregson, M. (2007) 'Endless Change In The Learning And Skills Sector: The Impact On Teaching Staff, Journal of Vocational Education and Training Vol. 59, No. 2, pp. 155-173. http://dx.doi.org/10.1080/13636820701342483

Eliahoo, R. (2008) Case Study On The Impact Of The New Mentoring Requirements On The Quality Of ITT In Adult And Community Learning. London: QIA.

Feldman, D.C. (1999) 'Toxic Mentors Or Toxic Protégés? A Critical Re-Examination Of Dysfunctional Mentoring’ Human Resource Management Review Vol. 9, No. 3, pp. 247-278. http://dx.doi.org/10.1016/S1053-4822(99)00021-2

FENTO (2001) Mentoring Towards Excellence. Coventry: LSC.

Fisher, R., Webb, K. (2006) 'Subject Specialist Pedagogy And Initial Teacher Training For The Learning And Skills Sector In England: The Context, A Response And Some Critical Issues' Journal of Further and Higher Education Vol. 30, No. 4, pp. 337-349. http://dx.doi.org/10.1080/03098770600965367

Hankey, J. (2004) 'The Good, the Bad and Other Considerations: Reflections on Mentoring Trainee Teachers in Post-compulsory Education', Research in Post-Compulsory Education Vol. 9, No. 3, pp. 389-400. http://dx.doi.org/10.1080/13596740400200185

Ingleby, E., Hunt, J. (2008) 'The CPD Needs Of Mentors In Post-Compulsory Initial Teacher Training In England' Journal of In-Service Education, Vol. 34, No. 1, pp. 61-74. http://dx.doi.org/10.1080/13674580701828237

Kram, K. (1985) 'Improving the Mentoring Process', Training and Development Journal Vol. 39, No. 4, pp. 40-43.

Lucas, N. (2007) 'Rethinking Initial Teacher Education For Further Education Teachers: From A Standards-Led To A Knowledge-Based Approach' Teaching Education Vol. 18, No. 2, pp. 93-106. http://dx.doi.org/10.1080/10476210701325077

McDowall-Long, K. (2004) 'Mentoring Relationships: Implications For Practitioners And Suggestions For Future Research', Human Resource Development International Vol. 7, No. 4, pp. 519-534. http://dx.doi.org/10.1080/1367886042000299816 
Noe, R.A. (1988) 'An Investigation Of The Determinants Of Successful Assigned Mentoring Relationships', Personnel Psychology Vol. 41, No. 1, pp. 457-479. http://dx.doi.org/10.1111/j.1744-6570.1988.tb00638.x

Ofsted (2003) The Initial Training Of Further Education Teachers: A Survey. London: Ofsted.

Ofsted (2006) The Initial Training Of Further Education Teachers. London: Ofsted.

Ofsted (2008a) The Initial Training Of Further Education Teachers: Findings From 2006/07 Inspections Of Courses Leading To National Awarding Body Qualifications. London: Ofsted.

Ofsted (2008b) The Annual Report of Her Majesty's Chief Inspector of Education, Children's Services and Skills 2007/08. Ofsted, London

Ofsted (2009) The Initial Training Of Further Education Teachers. London: Ofsted.

Rogers, C.R. (1969) Freedom to Learn. Columbus: Charles Merril.

Samson, A. (2008) The Impact Of The New Reforms On Teachers Of Vocation Subjects, Including Work-Based Learning: A Case Study. London: QIA.

Schon (1983) 'From Technical Rationality To Reflection-Inaction', in Harrison, R., Reeve, F., Hanson, A., Clarke, J. (eds) Supporting Lifelong Learning: Vol. 1: Perspectives on Learning. London: RoutledgeFalmer, p. 40-61.

Standards Unit (2007) ITT Pilot Resources. DfES Standards Unit.

Thomson, A. (2009) 'Sector exceeds success targets' Times Educational Supplement [online] Available at: www.tes.co.uk/article.aspx?storycode $=6011963$ [Accessed on 5 May 2009].

Thompson, R. and Robinson, D. (2008) 'Changing Step Or Marking Time?’ Teacher Education Reforms For The Learning And Skills Sector In England' Journal of Further and Higher Education Vol. 32, No. 2, pp. 161-173. http://dx.doi.org/10.1080/03098770801975330

Tusting, K., Barton, D. (2003) Models Of Adult Learning: A Literature Review. Leicester: NIACE. 